\title{
How conceptions of equity and justice shape national park negotiations: The case of Parc Adula, Switzerland
}

\author{
Annina Helena Michel
}

Keywords: justice, equity, protected areas, Parc Adula, Switzerland

\section{Abstract}

This article engages with conceptions of equity and justice in protected area negotiations and ties in with recent scientific discourses on the importance of social equity for successful biodiversity conservation. I follow the question of how conceptions of justice shaped discussions surrounding a national park project in Switzerland, Parc Adula. The project was rejected in a public vote in 2016. Drawing on qualitative interview data, this article analyses park negotiations and sheds light on a plurality of senses of justice. Whereas Parc Adula as a bottom-up project based on direct democracy already respected just procedures, perceptions of (in-)justice still informed day-to-day discussions and disputes. Thus, I argue that understanding justice as a process that reveals itself in disputes, and acknowledging its plurality, can help understand struggles over conservation and regional development.

\section{Profile}

Protected area

Parc Adula

Mountain range

Alps, Switzerland

\section{Introduction}

Social equity as a prerequisite for successful biodiversity conservation has been increasingly discussed in socio-ecological research in recent years (Chan \& Satterfield 2013; Franks et al. 2016; Martin 2017). Protected areas (PAs) in particular, as the key strategy for protecting biological resources, show how conservation effectiveness is linked to socio-economic outcomes (Oldekop et al. 2015). Equitable management approaches, such as the empowerment of local people and sharing of benefits, ensure PA success (Franks \& Schreckenberg 2016; Zafra-Calvo et al. 2017).

Franks and Schreckenberg (2016) introduced an equity framework to assess social equity in PAs, a framework which has been further discussed and expanded (see Martin 2017; Zafra-Calvo et al. 2017). The framework comprises principles organized in three interlinked dimensions (Table 1).

Whereas the equity framework does not include the active engagement of PA actors with notions of justice, this paper will engage with the day-to-day conception of (in-)justice. Equity and justice have often been used interchangeably in the conservation literature (Martin 2017). However, Martin (2017: 15) sees in justice a more inclusive term, which is "more often chosen by those involved in environmental struggles". Hence, I analyse the formation of a sense of justice by actors in a PA project and focus on mundane dilemmas over justice. In addition, I use the term equity as employed in Franks and Schreckenberg's (2016) assessment tool, since it adheres to the language of mainstream conservation, as used in the 2020 strategic targets for biodiversity in the United Nations Convention on Biological Diversity (Martin 2017). Thus, I understand social equity assessment in PAs in a more instrumental way (Franks et al. 2016).

This paper analyses social equity in planning, as well as day-to-day conceptions of justice in national park negotiations in Switzerland. Applying the equity framework (Franks \& Schreckenberg 2016; Zafra-Calvo et al. 2017), Swiss park politics follow an equitable approach to PA planning and management, respecting all three dimensions of the framework. Regarding procedural equity, a national park has to be initiated bottom-up, emerging from the region concerned, and should be established based on a participatory process and direct democracy (FOEN 2015). Accordingly, Hunold and Young (1998) describe a communicatively democratic process, which recognizes and respects the various interests of the actors involved, as a prerequisite for just planning procedures. Moreover, the park

Table 1 - Equity framework for protected areas (Franks \& Schreckenberg 2016; Zafra-Calvo et al. 2017).

\begin{tabular}{|l|l|l|}
\hline Recognition & Procedure & Distribution \\
\hline - Human rights & - Effective participation in decision making & - Effective mitigation of any costs to local \\
- Cultural identity & - Transparency & communities \\
- Statutory and customary rights & - Clearly defined and agreed responsibili- & - Beneftis shared among relevant actors \\
- Different values, knowledge systems and & ties of actors & - Benefits of the current generation do not \\
instituttions & - Accountability & compromise benefits to future generations \\
- Relevant actors, their diverse interests, & - Free prior and informed consent \\
concerns, capacities and powers to influ- & - Access to justice & \\
ence & - Identification and assessment of costs, & \\
- Non-discrimination & benefits and risks & \\
\hline
\end{tabular}




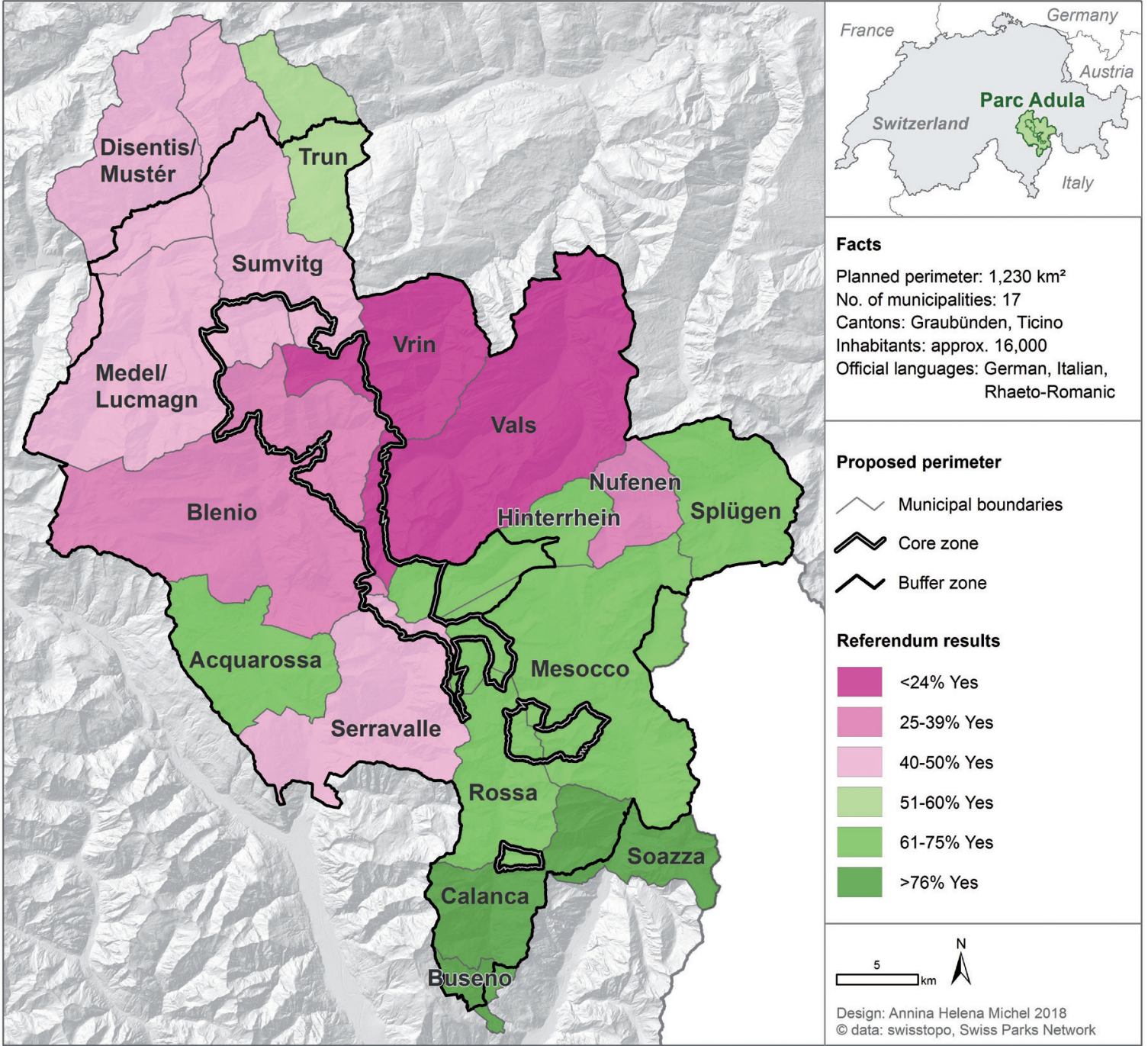

Figure 1 - Proposed perimeter and referendum results for Parc Adula.

label is meant to increase added value in the park's region through tourism and labelling of produce, an important rationale for distribution equity (Knaus \& Backhaus 2014; Knaus et al. 2017; Pichler-Koban \& Jungmeier 2015). Swiss park politics thus respond to the contemporary paradigm of PAs in central Europe with goals of sustainable regional development, and nature as well as cultural heritage conservation (FOEN 2015; Mose 2007).

I focus on the non-establishment of Parc Adula to understand how a presumably equitable national park project can nonetheless be rejected by the local population. The project was shelved after a no-vote at municipal level in 2016. Whereas participation and direct democracy assured procedural equity, the people involved and affected still articulated perceived injustices concerning the park project. This plurality of perceptions makes this case particularly interesting to analyse in respect of equity and justice. Hence, I will focus on different senses of justice, and follow the question of how they shaped park negotiations. For this purpose, I use pragmatic sociology and the work of Luc Boltanski and colleagues (Boltanski \&
Thévenot 1991, 2006; Boltanski 2012), who offer an approach for modelling different senses of justice and for engaging more effectively with a public debate and with its associated moral issues. By complementing the equity framework with pragmatic sociology, I achieve a very promising approach for understanding conceptions of justice in central European PA projects.

\section{Study area}

Parc Adula (central Adula peak located at $46^{\circ} 29^{\prime} \mathrm{N}$, $9^{\circ} 2^{\prime} \mathrm{E}$ ) was projected to become the first national park of a new generation of Swiss parks, in accordance with the Ordinance on Parks of National Importance, released in 2007. Such a new generation park would differentiate itself from Switzerland's current one and only national park by focusing on economic and social goals, veering away from traditional park objectives restricted to nature conservation and research (FOEN 2015). Parc Adula was initiated in 2001 by representatives of the local municipalities and was shelved after the negative outcome of the popular vote at municipal level in November 2016. Whereas the majority of mu- 
nicipalities said yes to the project, the park was nevertheless deemed unfeasible, since much of the park's core zone was to be located in no-voting municipalities (Figure 1).

\section{Methods}

Data was collected in 2015 and 2016, before the referendum on Parc Adula. A range of methods were used in order to help capture a wide variety of opinions from different actors and people affected by the park project. 17 semi-structured interviews (Flick 2009) were conducted with government, park management and NGO representatives, as well as with local residents actively involved in the Parc Adula project or in activities such as tourism. Additionally, 11 unstructured interviews (Schlehe 2003) were conducted with residents of the park region who had various levels of involvement. Other ethnographic methods were also used to reach further local residents. Open conversations, and participatory and non-participatory observations in the villages and at various events organized by the Parc Adula management team or affiliated groups, led to a more in-depth understanding of ongoing debates in the valleys (Angrosino 2007). Data analysis was conducted along the lines of Mayring's (2010) qualitative content analysis, using MaxQDA software. Interview quotations used in this paper were translated from Swiss German dialect to German and then into English. Back-translation was used to ensure accuracy.

\section{Theoretical framework}

To analyse and understand issues of justice concerning Parc Adula, I complement the equity framework (Franks \& Schreckenberg 2016) with approaches from pragmatic sociology. Pragmatic sociology breaks with more traditional sociological approaches that seek to associate social relationships with power relations (Boltanski 2012). Rather, it contributes to "empirical research on the way persons use their sense of justice to engage in critiques, justify their actions or veer towards agree- ment" (Boltanski 2012: 36). The focus is on how actors justify themselves in particular disputes, what criteria they invoke, and what their statements reveal about their sense of justice (Stones 2014). Actors actively engage in "everyday disputes of different - and, in many respects, competing - conceptions of justice" (Susen 2014: 7). I follow this idea of a plurality of conceptions of justice and use the work of Boltanski and Thévenot (1991, 2006) to understand how actors in conservation disputes try to reach agreements about what constitutes justice, which will further function as a legitimation of a decision-making process (see Turner 2014) - in this case, the possible establishment of a national park. Pragmatic sociology offers an active notion of justice as a process that involves active engagement by people; it is not simply an element of the law and social norms, or of scientific frameworks. This active engagement shows itself in non-violent disputes, and especially in the acts of justifying or criticizing perceived injustices (Turner 2014). Therefore, this approach is a promising addition to the equity framework, which focuses mostly on institutional structures and is understood as a more instrumentalist approach.

Boltanski and Thévenot (2006) analyse this active sense of justice as it manifests itself in everyday disputes. They introduced a framework that describes several justification regimes, called common worlds, which are based on different values and to which actors resort when facing criticism or trying to reach an agreement (Boltanski \& Chiapello 2018; Boltanski \& Thévenot 2006). In each world, people follow a particular higher common good or principle and evaluate the relative worth of people and their actions based on these principles. Hence, actors employ their dayto-day sense of justice based on different understandings of worth (Susen 2014). Boltanski and Thévenot apply the term worth instead of the more commonly used values, since worth, in contrast to values, is always oriented towards justice (Boltanski 2012).

There are seven worlds (presented in Table 2). Thévenot et al. (2000) also discuss a possible additional green worth, which includes an environmental vocabulary of justice. However, this eighth world is not as

Table 2 - The seven justification regimes (common worlds) and the possible green worth (adapted after Boltanski \& Chiapello 2005; Boltanski \& Thévenot 2006; Michel \& Backhaus 2018; Thévenot et al. 2000).

\begin{tabular}{|l|l|l|}
\hline Common world & Higher common principle & State of worthiness \\
\hline Inspired & Inspiration & $\begin{array}{l}\text { Inexpressible, bizarre, unusual, marvellous, unspeakable, disturbing, exciting, spontane- } \\
\text { ous, emotional }\end{array}$ \\
\hline Domestic & $\begin{array}{l}\text { Generation, hierachy, } \\
\text { tradition }\end{array}$ & $\begin{array}{l}\text { Hierarchical superiority, benevolent, well brought up, wise, distinguished, discreet, re- } \\
\text { served, trustworthy, honest, faithful }\end{array}$ \\
\hline Fame/renown & The reality of public opinion & $\begin{array}{l}\text { Famous, reputed, recognized, visible, success (to have), to distinguish (oneself), persua- } \\
\text { sive, attention-grabbing }\end{array}$ \\
\hline Civic & $\begin{array}{l}\text { The pre-eminence of col- } \\
\text { lectives }\end{array}$ & Rule-governed and representative, unitary, legal, official, authorized, confirmed \\
\hline Market & Competition & Desirable, valuable, saleable, millionaire, winner \\
\hline Industrial & Efficiency & Efficient, functional, reliable, operational \\
\hline $\begin{array}{l}\text { Project-orient- } \\
\text { ed/network }\end{array}$ & $\begin{array}{l}\text { Activity, project initiation, } \\
\text { remote links between people }\end{array}$ & $\begin{array}{l}\text { Adaptability, flexibility, polyvalence, sincerity in face-to-face encounters, ability to spread } \\
\text { the benefits of social connections }\end{array}$ \\
\hline Green & Environmental friendliness & Sustainability, renewability \\
\hline
\end{tabular}




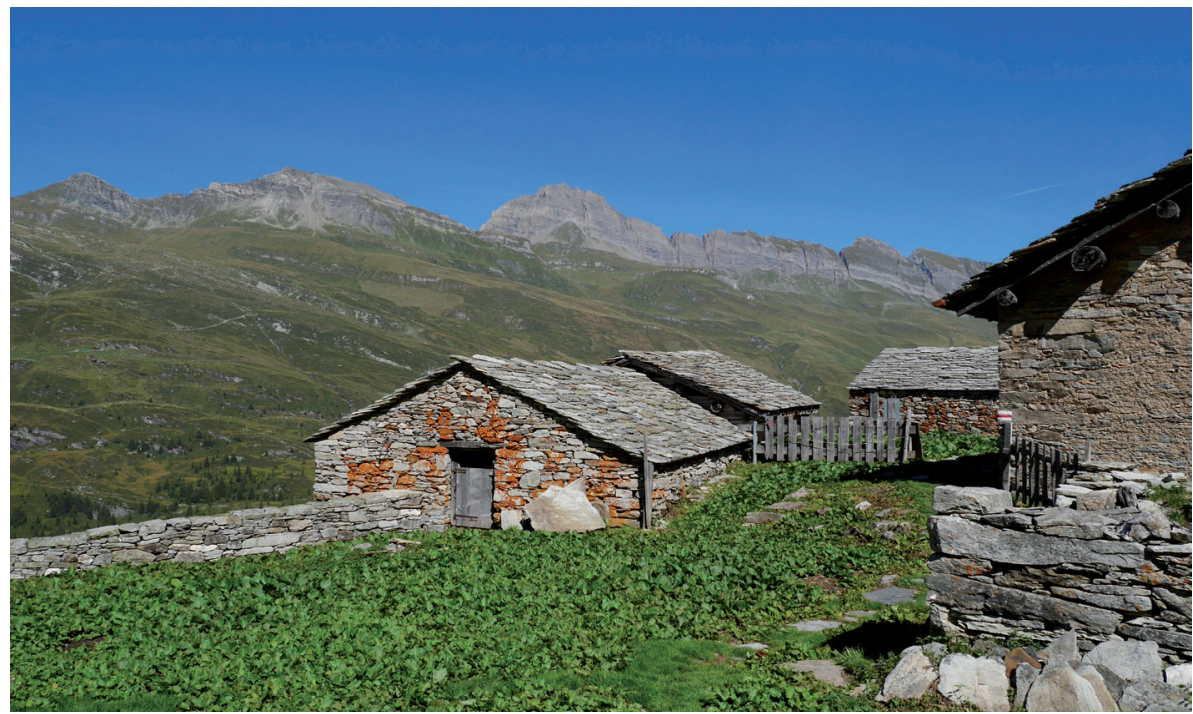

Figure 2 - Alp Ampervreila in the proposed buffer zone. (C) Michel

well illustrated or strongly integrated as the others and thus still lacks some theoretical coherence (Blok 2013; Thévenot et al. 2000). Nonetheless, in a conservation context, a possible green worth should be taken into consideration for a thorough analysis.

By engaging with definitions of what is good, the justification model helps us to look at how people express possible injustices, whereas their sense of justice shows in the justifications they provide to defend their stances. I therefore use this approach to better understand the demands for justice that emerged as criticisms and thus influenced negotiations in the Parc Adula case study.

\section{Discussion of findings: A pluralism of justice in park negotiations}

This section connects empirical results with theoretical approaches to equity and justice. As discussed above, the institutional and legal frame of Swiss park politics encompasses many equitable procedures. Nonetheless, different senses of (in-)justice, rooted in different worlds and surfacing in acts of justification, are an intrinsic part of social life and decision-making, shaping park negotiations. Thus, justice is evaluated not only by scientists using social equity assessments, but also by people affected by the park project. In a setting of direct democracy in particular, citizens are enabled to express assumptions about justice (Hunold \& Young 1998).

\section{Markets and outsiders}

In general, park proponents perceived Parc Adula as an economic opportunity and as a new source of added value - which facilitates distributional equity (Michel \& Backhaus 2018). Thus, these people justified their claims by referring especially to market (short-term profitability) and industrial (long-term efficiency) worth (Boltanski \& Thévenot 2006), expect- ing a boost for local tourism and trying to counteract structural disadvantages faced by this Alpine region. Martin (2017) follows Fraser (2000) in discussing structural disadvantages for rural residents, which manifest themselves in Switzerland's alpine valleys in the form of higher infrastructure costs or poor accessibility. Moreover, demographic changes such as falling birth rates, an aging population, and the brain drain also impact mountain regions (Müller-Jentsch 2017).

Where agriculture, an important economic sector in the region, is concerned, income is strongly dependent on direct payments, which ensure distributional equity (Müller-Jentsch 2017). Nonetheless, one interviewee saw the need for new income sources to ensure the future of the farmers in the valleys:

"Tust with agriculture on its own, these municipalities do not have a future. You can't always rely on direct payments, because at some point the government will have less money to give." (Local resident 12, interview 2016).

This interviewee shows a sense of justice oriented towards the future, and possibly future generations, a prerequisite for distributional equity. More precisely, this quotation connects time with market worth and thus charges it with questions of (intergenerational) justice. Although Boltanski and Thévenot (2006) follow a synchronic approach in their framework and hardly reflect on the future (Adkins 2014), temporality and the market world are deeply entangled in a world driven by constant transformation and acceleration (see Boltanski \& Chiapello 2018).

However, we must question here whether all the locals affected would have had the opportunity to profit financially from the park project. Martin (2017) criticizes a market-based approach as the solution to injustices in conservation, since such neoliberal mechanisms are not altruistic. Boltanski and Thévenot (2006: 15) also describe a problem with market justifications, since a sense of injustice can be "aroused when different 
orders of justice are confused, and especially when justifications of a market order are extended beyond their legitimate boundaries" - in this case extending into nature conservation.

In contrast, opponents to the park conceptualized a different sense of justice. Adversaries did not believe in an economic upturn, or did not see a need for change or additional support for the economic sector. This perception opposes scientific and political points of view (or, as described in the interviews, urban ideas) regarding regional development through the establishment of the park. These urban ideas are based on a solid foundation of civic justifications, aiming for solidarity with structurally disadvantaged regions and thus implementing a universal approach to justice. Critiques of urban ideas stem from feelings of belonging and heritage (i.e. arguments in the domestic world), which only recognize "the worth of personal attachments" (Boltanski \& Thévenot 2006: 243). Martin (2017: 92) describes this reification of in-group identity as possibly being politically problematic, since it can "provide the power of social mobilization against abusive states, but it can also lead to separatism and intolerance, seeking in-group advantages rather than universal justice". In-group identity and the worth of personal attachments formed a basis for justifying criticism of the park project as being unjust. The following extract from an interview shows a strong perception of injustice, rooting justifications in domestic worth:

"...we have to be somehow a zoo or the museum for what is built over in the cities, all that was ruined. (...) now we are almost the only ones that still have something to be protected." (Local farmer, interview cited in Haggenmacher 2017, own translation).

Whereas this person perceived the park as something restricting, the following quotation shows how the possible restrictions posed by a park can be conceptualized differently. Based on a different sense of justice, this statement underlines the complexity of justice pluralism.

"For me this is a question of loss or gain of freedom. Loss in the sense that I can't leave the [biking] trails. But the gain is that I get new possibilities here. I get a choice. Otherwise I don't have a choice and therefore have no freedom. I would have to go to Zurich to work." (Local resident 11, interview 2016).

This interviewee brings up a very interesting rationale. Considering the orders of worth, this person expresses a sense of justice based on the civic world (Boltanski \& Thévenot 2006). The quote acknowledges the (state) authority and calls for solidarity and equality in terms of freedom of choice between urban (Zurich) and rural areas. In terms of the equity framework, this opinion transcends distribution equity (a place to work, income) and moves towards recognition equity. Kompridis (2007) understands recognition as a struggle over how we wish to be governed. Misrecognition would impede the freedom to govern oneself (Kompridis 2007). This struggle is explicitly pictured by the interviewee above and translates into a sense of justice tied to freedom of choice.
Competing senses of justice and their complexity form an unstable foundation for park negotiations and conservation politics, raising the question $I s$ direct democracy the solution for just conservation objectives?.

\section{Direct democracy for equity and justice}

Direct democracy as part of Swiss federalism adds to the uniqueness of the Parc Adula case. It ensures procedural equity in PAs (Martin 2017). Boltanski and Thévenot (2006: 192) confine democracy to the civic world, describing it as "the most appropriate political form for the manifestation of the general will". Direct democracy is fundamentally accepted in Swiss society as a legitimate way of decision-making. Swiss federalism and a shared commitment to the same political values as well as the internalized acceptance of these political structures from local to federal level are important elements of Swiss culture (Fleiner 2002). Within Switzerland, federalism thus creates a sense of justice that is accepted on a broad basis, as reflected here:

"I am confident [about Parc Adula] and if it results in a No, then it is a democratic decision." (Local resident 13, interview 2016).

As well as presenting a high level of procedural equity, a communal referendum also respects local agendas and prevents overruling by urban ideas (Christmann \& Danaci 2012). Hence, it is important for recognition equity in nature conservation and regional planning, and it also strongly corresponds to the civic world which has solidarity and the collective at its heart (Boltanski \& Thévenot 2006). However, direct democracy can also induce questions about justice, for example regarding certain procedures (such as voting in assemblies by show of hands versus balloting) or the geographical inclusion of voters, as is illustrated in the following quotation:

"Generally speaking, the project is just, because there will be a vote on it. The question is, is it fair that maybe 30 people from a village in Blenio can decide about such a project that is important for the whole of Switzerland?" (Local resident 11, interview 2016).

Although voting procedures are generally accepted and thus were hardly a topic before the public vote, this interviewee questioned procedural equity, referring to a sense of justice situated in the civic world.

Parc Adula as a bottom-up project largely respected procedural equity, and residents were able to participate in the planning process before the vote. Local residents received information on the process via media outlets, such as a website and brochures distributed to households, and were able to ask questions at information events. Further, individuals and associations were able to object to the Charta, the park management plan, released to the public in late 2015 , giving them the opportunity for decisional participation (Pimbert \& Pretty 1995; Oxley Green \& Hunton-Clarke 2003). Nonetheless, the empirical data shows that the park opponents' sense of justice does not quite correspond to these understandings of equity. 
In reality, most opponents did not perceive the project as bottom-up, but rather that the outside would be deciding on the region (Michel \& Backhaus 2018). Moreover, the role of the federal and cantonal governments was often unclear to local residents. Bern as a metaphor for the federal government was often used in anti-park rationales, such as "Bern is coming and buying our forests" (local resident 4, interview 2015). Here, the government as an institution was perceived as detached from people, as an obscure bodiless entity. Boltanski and Thévenot (2006: 239) discuss such criticism in the context of the inspirational world, referring to "the inhuman state". In the interviews conducted for this study, this critique was often mixed with the domestic world, resulting in mistrust, since the federal and cantonal governments are not part of the local trusted community. During an information event shortly before the referendum, one local expressed the fear that, once the park was established, the government would always side with environmental NGOs in objecting to future construction projects. This was in some cases perceived as paternalism and fed discourses on injustice in the anti-park faction.

In the Parc Adula case, the public vote put an end, at least temporarily, to the dispute. Although Boltanski and Thévenot (2006) do not reflect upon referenda, the public vote can be considered a relativization, " $a$ moment that suspends a clash" (Boltanski \& Thévenot 2006: 340). Negotiation can thus be resumed with the passage of time (i.e. after the referendum); a referendum could also be contested or ignite new negotiations. This adds to the great uncertainty in PA planning, but simultaneously direct democracy is a prerequisite for justice.

\section{Conclusion}

People engage with a plurality of conceptions of justice in everyday situations and disputes. A sense of justice is intrinsic to social life and thus part of most decision-making processes. The obvious plurality within park negotiations underlines Martin's (2017: 56) approach to conservation justice, where he reminds us that "environmental conflicts occur between competing conceptions of justice rather than between just and unjust acts per se". A sense of injustice is aroused when different orders of justice are confused (Boltanski \& Thévenot 2006: 15), or when justifications are present that transcend the situation (Boltanski \& Thévenot 2006). It is these confused senses of justice that shaped negotiations in the Parc Adula case study, and not perceptions or objective assessments of social equity in park planning. Therefore, the addition of approaches from pragmatic sociology to equity assessments proves to be very valuable in PA research. Regarding Parc Adula, an analysis using the equity framework (Franks \& Schreckenberg 2016) alone would not account for the no-vote. Rather, a clash between senses of justice pertaining to different common worlds can weaken a presumably equitable conservation approach. Importantly, such a clash can also strengthen the argument to follow a pluralist understanding of justice as a process and not as a static ideal.

We need to question what the underlying principles of worth within conservation policies are that lead to such differing perceptions of justice, values or identities (see Fraser 2000; Martin 2017). Therefore, conservation and regional development projects have both to follow and to communicate a clear set of values (or worths) and adjust these to local citizens' plural senses of justice. Swiss direct democracy, with its participatory characteristics, is a legitimate procedure that already values different conceptions of justice and is a prerequisite for the achievement of just conservation and regional development.

In conclusion, it is worth considering whether a differentiated use of the terms equity and justice would make sense in PA project assessment more widely, and even more so in planning. I argue (along with Martin 2017) that justice, as inclusive of scale and time, and understood as a process intrinsic to everyday disputes, is a term that accounts for a broader set of challenges in PA establishment and is thus a more comprehensive term to use than equity.

\section{Acknowledgment}

This study is funded by the Swiss National Science Foundation (SNSF), project 10001A_152785 9: Morality and the development of national parks: Social and political negotiations in Abel Tasman National Park (New Zealand) and in Park Adula (Switzerland).

\section{References}

Adkins, L. 2014. Luc Boltanski and the Problem of Time: Notes towards a Pragmatic Sociology of the Future. In: Susen, S. \& B.S. Turner (eds.), The Spirit of Luc Boltanski: Essays on the Pragmatic Sociology of Critique': 517-538. London.

Angrosino, M. 2007. Doing Ethnographic and Observational Research. London.

Blok, A. 2013. Pragmatic sociology as political ecology: On the many worths of nature(s). European Journal of Social Theory 16(4): 492-510.

Boltanski, L. 2012. Love and Justice as Competences. Cambridge, Malden.

Boltanski, L. \& E. Chiapello 2005. The New Spirit of Capitalism. International Journal of Politics, Culture, and Society 18(3/4): 161-188.

Boltanski, L. \& E. Chiapello 2018. The New Spirit of Capitalism. $2^{\text {nd }} \mathrm{ed}$. London, New York.

Boltanski, L. \& L. Thévenot 1991. De la justification. Les économies de la grandeur. Paris.

Boltanski L. \& L. Thévenot 2006. On Justification. Economies of Worth. Princeton, Oxford. 
Chan, K.M.A. \& T. Satterfield 2013. Justice, Equity and Biodiversity. In: Levin, S. (ed.), Encyclopedia of Biodiversity. $2^{\text {nd }}$ ed: 434-441. New Jersey.

Christmann, A. \& D. Danaci 2012. Direct Democracy and Minority Rights: Direct and Indirect Effects on Religious Minorities in Switzerland. Politics and Religion 5(1): 133-160.

Fleiner, T. 2002. Recent Developments in Swiss Federalism. Publius: The Journal of Federalism 32(2): 97-123.

Flick, U. 2009. An Introduction to Qualitative Research. $4^{\text {th }}$ ed.

FOEN (Federal Office for the Environment) 2015. Anforderungen, Errichtung und Betrieb von Pärken. Available at: https://www.bafu.admin.ch/bafu/ de/home/themen/landschaft/fachinformationen/ landschaftsqualitaet-erhalten-und-entwickeln/ landschaften-von-nationaler-beeutung/paerke-vonnationaler-bedeutung/anforderungen--errichtungund-betrieb-von-paerken.html (accessed: 30/01/18). [In German]

Franks, P. \& K. Schreckenberg 2016. Advancing equity in protected area conservation. IIED Briefing, February 2016. London.

Franks, P., A. Martin \& K. Schreckenberg 2016. From livelihoods to equity for better protected area conservation. IIED Briefing, August 2016. London.

Fraser, N. 2000. Rethinking Recognition. New Left Review 3: 107-120.

Haggenmacher, M. 2017. Landwirtschaft und Naturschutzprojekte. Eine Untersuchung zur Wabrnebmung der Landwirtinnen und Landwirte am Beispiel des Nationalparkprojekts Parc Adula. Master Thesis, University of $\mathrm{Zu}-$ rich. [In German]

Hunold, C. \& I.M. Young 1998. Justice, Democracy, and Hazardous Siting. Political Studies 46(1): 82-95.

Knaus F \& N. Backhaus 2014. The Economic Impact of Tourism in Swiss Parks. Swiss Academies Factsheet 9(3). Bern.

Knaus, F., L. Ketterer Bonnelame \& D. Siegrist 2017. The Economic Impact of Labeled Regional Products: The Experience of the UNESCO Biosphere Reserve Entlebuch. Mountain Research and Development 37(1): 121-130.

Kompridis, N. 2007. Struggling over the Meaning of Recognition. A Matter of Identity, Justice, or Freedom? European Journal of Political Theory 6(3): 227-289.

Martin, A. 2017. Just Conservation. Biodiversity, Wellbeing and Sustainability. Abingdon, New York.

Mayring, P. 2010. Qualitative Inhaltsanalyse. Grundlagen und Techniken. $11^{\text {th }}$ ed. Weinheim, Basel.

Michel, A.H. \& N. Backhaus 2018. Unravelling reasons for the non-establishment of protected areas: Justification regimes and principles of worth in a Swiss national park project. Forthcoming in Environmental Values.

Mose, I. (ed.) 2007. Protected Areas and Regional Development in Europe. Towards a New Model for the $21^{\text {st }}$ Century: 3-20. Aldershot.
Müller-Jentsch, D. 2017. Strukturwandel im Schweizer Berggebiet. Strategien zur Erschliessung neuer Wertschöpfungsquellen. Zürich. [In German]

Oldekop, J.A., G. Holmes, W.E. Harris \& K.L. Evans 2015. A global assessment of the social and conservation outcomes of protected areas. Conservation Biology 30(1): 133-141.

Oxley Green, A. \& L. Hunton-Clarke 2003. A typology of stakeholder participation for company environmental decision-making. Business Strategy and the Environment 12: 292-299.

Pichler-Koban, C. \& M. Jungmeier 2015. Naturschutr, Werte, Wandel. Die Geschichte ausgewählter Schutzgebiete in Deutschland, Österreich und der Schweiz. Bern. [In German]

Pimbert, M. \& J. Pretty 1995. Parks, People and Professionals: Putting 'Participation' into Protected Area Management. Discussion Paper 57, February 1995. Geneva.

Schlehe, J. 2003. Formen qualitativer ethnographischer Interviews. In: Beer, B. (ed.), Methoden und Techniken der Feldforschung: 71-93. Berlin. [In German]

Susen, S. 2014. The Spirit of Luc Boltanski: Chapter Outline. In: Susen, S. \& B.S. Turner (eds.), The Spirit of Luc Boltanski: Essays on the Pragmatic Sociology of Critique': 49-64. London.

Stones, R. 2014. Strengths and Limitations of Luc Boltanski's On Critique. In: Susen, S. \& B.S. Turner (eds.), The Spirit of Luc Boltanski: Essays on the Pragmatic Sociology of Critique': 211-233. London.

Thévenot, L., M. Moody \& C. Lafaye 2000. Forms of valuing nature: arguments and modes of justification in French and American environmental disputes. In: Lamont, M. \& L. Thévenot (eds.), Rethinking comparative cultural sociology; repertoires of evaluation in France and the United States: 229-272. Cambridge.

Turner, B.S. 2014. Three Theories of Justice: Preliminary Reflections. In: Susen, S. \& B.S. Turner (eds.), The Spirit of Luc Boltanski: Essays on the Pragmatic Sociology of Critique': 29-47. London.

Zafra-Calvo, N., U. Pascual, D. Brockington, B. Coolsaet, J.A. Cortes-Vasquez, N. Gross-Camp, I. Palomo \& N.D. Burges 2017. Towards and indicator system to assess equitable management in protected areas. Biological Conservation 211: 134-141.

\section{Author}

Annina Helena Michel

is a PhD candidate in the Department of Geography, University of Zurich. Her main research interests are human-environment relationships, social dimensions of nature conservation, and social and political negotiations in protected areas. E-mail: annina. michel@geo.uzh.ch 